\title{
CROSS-LANGUAGES FIGURATIVENESS IN TRANSLATOR'S SPEECH (BASED ON RUSSIAN TRANSLATION OF TURKISH NOVEL "THE BLACK BOOK" BY ORHAN PAMUK)
}

\author{
E.A. Yurina, A.V. Borovkova, G. Shenkal \\ Tomsk State University (Tomsk, Russian Federation). \\ E-mail: yourina2007@yandex.ru; nastya-borovkova@mail.ru; gokselcha@gmail.com
}

\begin{abstract}
The study deals with cross-languages figurativeness as a metalanguage category, characterizing the speech of a bilingual speaker. The metalanguage category is researched using Russian translation of Turkish novel "The Black Book" by Orhan Pamuk. Russian variants of Turkish imagebearing vocabulary units and text fragments proposed by a professional translator V. Feonova are evaluated in terms of their structural and semantic equivalency to the original.
\end{abstract}

Keywords: cross-languages figurativeness; literary translation; cognitive metaphor; image-bearing vocabulary; phraseology.

\section{Introduction}

Figurative aspect of language means being an explicator of a national language world image as well as figurativeness of language created by the author (author's linguistic world image) in a literary work to reflect his personal vision of the world is a topical research issue in modern linguistics. National language world picture determines cultural and associative background of a literary text as the author is regarded as a native speaker and a prominent representative of the culture he belongs to. This background is transparent for readers - native speakers and representatives of the same culture. However, problems of adequate transfer of the author's images, expressed in the text using linguistic means of the native language, into a foreign language (especially if a language does not belong to the same language family) may arise concerning accuracy of conceptual meaning as well as figurative and symbolic cultural associations. A translator of a literary text has to be aware of figurative vocabulary and stylistic means, encompassing figurative charge of a literary piece while providing an adequate translation.

Figurativeness as a linguistic category is defined as a quality of language and text units to denote a fragment of reality (object, quality, process, situation) allegorically by analogy with a definite fragment of reality (object, quality, process, situation). Words and expressions are considered figurative if they are characterized by two dimensional semantics. Their relational notional meaning is expressed metaphorically or metonymically: by pointing at 
original percept-image, expressing meaningful characteristics of denoted phenomena, allegorically. Typical figurative representations of a national culture communicated by the semantics of figurative lexical and phraseological units are based on universal cognitive metaphorical and metonymical models which are characteristic to human cognition [1].

Semasiological and cognitive-discourse theory of figurativeness is discussed in Russian linguistics in the works of such authors as N.F. Alefirenko [2], N.A. Ilyuchina [3], N.A. Luk'yanova [4], G.N. Sklyarevskaya [5], V.N. Teliya [6], etc. The authors of the article also make references to the works of researchers from Tomsk linguistic school founded by O.I. Blinova [7] and E.A. Yurina [1,7]. The concept of language figurativeness is also presented in the works of foreign linguists, such as V. Evans [8, 9], S. Glucksberg [10], W. Raymond, Jr. Gibbs [11]. Cognitive aspect of figurativeness theory is based on widely recognized ideas by of G. Lakoff and M. Johnson [12], which were further developed in the framework of modern cognitive theory of metaphor by R. Gibbs [13], A. Barcelona [14], A.N. Baranov [15], A.P. Chudinov [16] and others.

Cross-language translation of figurativeness in a literary work is one of the most challenging and important tasks for a translator. Various aspects of this problem are presented in the concept of cross-language lexical and phraseological equivalency in translation theory [17-22], as well as in the works dealing with typological study of metaphors and figurative systems of different languages [23-27].

The purpose of this article is to study interaction of figurative systems of different languages in the process of translation. The interaction is defined as decoding of the figurative system of the source-language and its conversion to the figurative system of the target-language - native language of a translator. The original text of Turkish novel by Orhan Pamuk "Kara Kitap" [28] and the text of its translation into Russian by V. Feonova [29] serve as material for the given study. The original text and the translation of the novel are rich in figurative language units and are highly metaphorical. It can be explained by a semantic and stylistic multilayered nature of the novel whose detective plot is combined with sketch-publicistic analysis of the history and current situation in Turkey and with symbolic, mythological cultural context of the Islamic East. As a result, the translator had to preserve metaphorical nature and figurativeness of the original text in the condition of structural and typological language difference as well as Slavic and Turkic cultural mismatch.

\section{Research}

\section{Methodology}

Russian and Turkish pairs of identical or semantically close figurative words and expressions proposed by a translator as cross language 
equivalents are regarded as the smallest units for the analysis. 1089 Russian figurative words and expressions were collected by continuous sampling from a target text, these units were matched with their Turkish equivalents from the source text and their cross language figurative equivalency was evaluated. The units under analysis were represented by figurative lexemes, language metaphors, set figurative comparisons, figurative idioms and author's metaphor, which either match or differ structurally in two languages.

Language metaphors - are semantically motivated image-bearing units with figurative metaphorical meaning. As a rule, language metaphors are presented in the dictionary and have a fixed meaning. For example, issyaknut' "to end up, to run dry cf. the water ran dry in the spring" (in the translated text - issyaklo voobrazhenie) which is used by the translator for the Turkish metaphor kurumak (lit.: dry up) in the expression hayâlgücü $\boldsymbol{k u}$ ruduğu (lit.: imagination dried up); the Russian metaphor krutit'sya v golove "to appear in one's mind" (about thoughts and images) literally matches the Turkish metaphor aklının içinde olup biten harika şeyleri (lit.: wonderful things that are spinning in head); the Turkish metaphor o sihirli ilacı (lit.: magic medicine) is translated by a figurative word chudodeystvennoe lekarstvo (wonder drug).

Speech metaphors - context defined metaphorical text word-usages, which are not registered in the dictionary but are constructed in accordance with typical metaphorical models and are easily recognized and interpreted, for example: b'yutsya drug o druga bukvy (letters hit one another) (harflerin birbirine nasıl vurulacağını); bezdonnyy kolodez ikh pamyati (bottomless memory well) (hafizalarınin dipsiz kuyusuna); on byl spuschen na vodu voennym perevorotom (it was put afloat as a result of a military coup)(askeri darbenin deniz eindirildiği).

Author's metaphors - occasional metaphors which are unique by their metaphoric transfer and are not part of the language conventional conceptual system; such metaphors reflect the author's personal aesthetic image of the world: Pamyat' - eto sad (memory is a garden) (Hafiza bir bahçedir), gorod-son (city is a dream) (rüyaşehirden), boyus' videt na lizach mrachnye bukvy (I am afraid to see gloomy letters on faces) (harflerin karanlık yüzlerinden korkuyorum).

Phraseological units - semantically indivisible, fixed combinations which are characterized by a stable holistic meaning of a component structure: kozha da kosti 'very skinny (about a person)'; chto igolkoy kolodez kopat" "to do a labor-intensive and time-consuming activity" (iğneyle kuyu kazar gib); peresazhivaemsya s loshadi na ishaka! 'to descend to a lower level (about quality of life)' (attan inip eșeğe biniyoruz, hayırlı olsun!). 


\section{Hypotheses}

Comparative study of Russian-Turkish image-bearing vocabulary units reveals cross language figurativeness as a mental category characterizing interplay of figurative verbalizing codes reflecting vision of the world. These codes are in meta-linguistic perception of a translator and belong to different language systems. Cross-languages figurativeness was researched in the works by E.V. Karmazkaya [30], where it is presented as a unity of representations in the form of images, pictures, frames appearing in the mind of a non native speaker perceiving image-bearing vocabulary units of a foreign language. Following this idea, N.F. Aliferenko speaks about crosslanguage figurativeness of phraseological units, assuring "possibility of phraseological figurativeness transfer cross-linguistically" [2: 52]. According to N.F. Aliferenko cross-language phraseological figurativeness "is based on the reference ability of mental modeling in the cognition of native speakers of different languages during the perception of cognitive discourse contour of related phrasemes" [Ibid: 53].

We understand cross-language figurativeness as a metalinguistic and metatext category being part of language cognition of a bilingual person and actualized during the process of decoding of figurative system of a native or a second language into another language correspondingly during cross language communication. Decoding of native language figurativeness is done automatically without any cognitive effort, while decoding of foreign language figurativeness can be communicatively difficult which is determined by language and culture knowledge. Only in case of high communicative competence in foreign language decoding of figurativeness into native language will be successful. A decoding process of native language figurativeness into a foreign language is seen as the most difficult which is proved by the results of psycholinguistic translation study employing Turkish and English metaphors done by A.P. Saygin [27]. The difficulty is explained by the fact that language cognition of a native speaker incorporates the whole system of metaphorical models and figurative meanings (typical for a particular lingua-culture), which are transmitted by the system of figurative means of a native language. In the context of a foreign language a speaker perceiving conceptual meaning of a foreign language easily finds an equivalent for an image-bearing vocabulary unit from the native system of metaphorical models and figurative meanings. The situation is reverse in case of decoding native figurativeness into a foreign language: not possessing the figurative code of a foreign language in full, the speaker has to use extended descriptions to convey figurative meaning which can lead to an inevitable loss of expressive and cultural connotations.

Translation of metaphorically loaded texts emphasizes cross language figurativeness as a cognitive category which determines tactics and strategies 
of translator's speech activity. The strategy aimed at preservation of figurative meaning of the text determines the tactics of equivalent translation of an image-bearing vocabulary unit and search for such foreign language imagebearing units which are capable to create the same effect of figurativeness which a native reader obtains while reading the original.

Purpose. The purpose of the given research is to conduct a comparative analysis of image-bearing vocabulary units presented in the target text in terms of their structural, semantic, stylistic and cultural equivalency match to language units of the source text. The analysis of such kind will help reveal the type of cross language figurativeness explicated in the speech activity of the Russian translator while working with the Turkish literary text.

Findings and Analysis. At the first stage of the analysis image-bearing lexical and phraseological units were identified in the source and target texts. Then semantically related Russian-Turkish pairs which were explicated in translator's activity as image-bearing equivalents were matched. For example, the Russian image-bearing unit unizit' "offend, insult, figuratively, place in a lower position by offensive words and actions" is an equivalent to the Turkish image-bearing unit küçümsemek "offend, insult, figuratively, make smaller by offensive words and actions".

At the second stage a comparative analysis the Russian-Turkish equivalents semantics as well as their text realization was done to measure degree of equivalency between lexical figurative systems of the source and the target texts in terms of language and literary image translation accuracy.

At the next stage semantics and text realization of related Turkish image-bearing units from the source text were evaluated in accordance with the following criteria: 1) match or mismatch of image-bearing language units used by the author and the translator; 2) match or mismatch of a direct concept meaning of image-bearing language units; 3) match or mismatch of an image ground of the units in the source and target texts; 4) match or mismatch of evaluative connotations; 5) match or mismatch of culture and symbolic associations.

Complete semantic and structural match was found in such metaphors as: rus. utonut'v podushke "o sink in a pillow" - turk. yastı̆g gömülmek; rus. proskol'znut' "to pass by unnoticed" - turk. süzülmek; rus. rayskoe mesto "a place of paradise" - tur. cennetyer; such image-bearing words with metaphoric inner form as: rus. nevynosimyy chelovek "with unbearable character, which is figuratively impossible to bear (about a person)" - turk. dayanılmaz kişi olacağıma originated from a Turkish verb dayanmak "to hold, to bear some weight", lit.: a person whom it is impossible to hold; such phraseologisms as: rus. kozha da kosti "about someone who is very skinny" turk. bir deri bir kemik (lit.: just skin, just bones); such author's metaphors as: "neterpenie, kotoroe, kazalos', vot vot perel'etsya cherez kray, kak sbezhavshee moloko" lit. impatience which looks as if it will slop over like a 
ran away milk - turk. "kaynayarak birdenbire taşan bir tencere sütün tatsızlı̆̆ılyla içinde hissetti”.

Lack of structural equivalency was found in cases of formal structure mismatch of image-bearing language units in the source and the target texts. For example, image-bearing comparison in the source text is translated by a language metaphor: nefesi ttkanir gibi lit.: as if gasping - perechvatyvalo dychanie (o chuvstve vostorga, volneniya) "took one's breath away" (about delight, excitment).

There are cases in the target text where the Turkish metaphor is translated by the Russian one which is its full conceptual equivalent but there is a mismatch in their image grounding. For example, Turkish kendi iradesinin saflı̆̆ını bozan (lit.: razrushali chistotu ego voli "were breaking cleanness of his will") is translated as razrushali tverdost' ego voli "were breaking his tenacity". The translator could have been motivated by a common collocation use of Russian metaphors: tverdaya volya "hard will", but chistota pomyslov "heavenly thoughts". As a result, despite high equivalency in conceptual meaning the difference in image grounding causes differences in shades of meaning. For example, the character in the source text betrays his principles because of bad influence and it is accentuated that something had spoiled him, destroyed his innate purity while in the target text it was the ability of the character to counter bad influence that deteriorated and his will weakened.

The analysis resulted in the following five levels of equivalency:

1. Complete equivalency - the translation and the original are semantically, structurally and pragmatically identical. For example, the Russian phraseologism odnim machom "quickly, instantly" lit.: za vremya vzmacha ruki "for the period of a hand wave" totally corresponds to the Turkish phraseologism birçırpıdac by the same image grounding. Comparative structure slasche meda "about the feeling of emotional pleasure compared with a pleasant taste of honey" is identical to the Turkish baldan tatll.

2. Equivalency of high degree is assured by the match in characteristic features of an image-bearing unit, unity of conceptual meaning, proximity of connotations along with the mismatch of initial image grounding. Rus. tverdo znal (originally from the adjective hard "resisting mechanical deformation, retaining its structure") corresponds to adı gibi biliyordu (lit.: knew as his own name); rus. chudodeystvennoe lekarstvo - turk. sihirli ilaç (lit.: magic medicine).

3. Partial equivalency is determined by the image bearing characteristics of a language unit in the source and the target texts and preservation of conceptual meaning but there is a mismatch in original image grounding: ubit' beskonechnye chasy "to kill infinite hours" - sonsuzluk saatini doldurmaya (lit: to fill in infinite time); ostro oschutil "lit. to sense sharply" duygusuna kapıldı (lit.: appeared in the flow of feelings); iz kozhi von lezut 
"lit. crawling out of their skin" - can attıkların (lit.: ready to give their souls away).

4. Equivalency of low degree is found in cases when only general meaning is conveyed with the help of image-bearing language units which do not have direct equivalents in the source language: predal smerti (lit. brought to death) - idam ettirdiğini (lit: ordered to kill them); rus. prokruchival v golove lit. spinned in his head - turk. yeniden kuruyordu (thought constantly, lit: wound like watch in his head).

5. Zero equivalency (absence of equivalency) is found when the image-bearing language unit is translated descriptively as there are no corresponding image-bearing language unit in Russian: emu stalo strashno (lit. he got scared) - bu anlamlarar asında kaybolabileceği de geldi aklına (lit.: he can get lost in this meanings / thoughts); on ne umeet rasskazyvat" "he can't tell stories" - parlak olabilmeyi bilmiyor (lit.: he can't be bright).

\section{Conclusion}

The analysis revealed that while translating figurative system of the Turkish language the Russian translator decoded allegorically (figuratively, metaphorically, symbolically) expressed meanings using the Russian language image-bearing vocabulary recourses. This process outlined universal and culturally specific features of cross language figurativeness within two studied systems. Universal status of cross language figurativeness is assured, firstly, by the presence of basic metaphorical models, singled out by Lakoff and Johnson [12], which assure similarity of images grounded on the same mental schemes. Orientational and container metaphors are among these (rus. ogranichivat' lit. to border - turk. kisitlamak 'to deprive of freedom; rus. opustoshennyy "desolated" - turk. boşalmış "disappointed, the one who lost his ideal (about a person)"). Secondly, it is achieved by similarity of sentient experience, similarity of physiological, psychological and social qualities being universal for all people (rus. gorech" "bitterness" - turk. actyla "a sense of sadness, grief, having a bitter taste"; rus. osleplennyy "blinded" turk. körolmuştu "being totally influenced by smb., lacking critical mind").

The differences in figurative systems are rooted in peculiar ways of linguistic coding of universal meanings (rus. ich sny perepletalis' "their dreams interwove" - turk. rüyalarının birbirine karıştığına (lit.: mixed), with national peculiarity of cultural tradition (rus. lizo stalo pustym "the face got empty" - turk. huzurla bakan yüzü, kinalar sürülmüss kurbanlık bir koyununki kadarboşmuş artık (lit.: the face looks calmly as if a sheep daubed by alcanna, which will be sacrificed).

Structural and semantic similarity is the highest while translating linguistic, speech and author's metaphors i.e. the Russian image-bearing language unit matches the Turkish image-bearing language unit structurally 
during translation. There is only partial equivalency; high equivalency is rare, while translating linguistic metaphors from Turkish into Russian. It is explained by the fact that Turkish metaphors are culturally marked and are not registered in dictionaries and other written sources. Typical images, represented by Turkish metaphors, do not often match images of the native Russians. As a result there is incomplete equivalency in translation. For example, language metaphor vospominaniya uskol'zayut ot menya "memories slide away from me", used in the target text, is only partially equivalent to benden kaçan anılarımın (lit.: ran away from me memories).

The translator managed to reach complete equivalency while translating the author's metaphors. Despite the fact that such metaphors reflect aesthetic vision of the author and are fresh and original, their translation does not require much effort. Translation of speech metaphors is characterized by the same feature. Speech metaphors are also occasional and are not registered in the language system, and the translator easily translates their meaning in a relatively full manner. For example, rus. vyrastaet ego istinnyy golos "individual writing manner, original vision and evaluation of the situation is strengthened" (about the work of the reporter, his articles) literally corresponds to the Turkish metaphorical construction kendi gerçek sesinin yükselişine, having the same semantics.

Phraseological units having no equivalents are the most difficult to translate. Thus, while translating idioms the translator changes them into the Russian metaphors carrying a similar image. For example, such idiom as yüreklerine ateşler düşüren "inspire by ideas" (lit.: throw fire in their hearts) is translated by personification tronut' serdza "lit. to touch hearts". In some cases figurativeness of the source text is lost as only conceptual meaning of an image-bearing language unit is translated. For example, turk. Ayağlkesilince (lit: legs cut into ground meaning "somebody stayed at some place for a long time, "got stuck somewhere", that is why he stopped appearing in public") in the following context "saat tamircisin in pavyondan aya $\breve{g}$ kesilince" is translated into Russian "chasovoy master vdrug propal" "watch master suddenly disappeared".

Direct conceptual meaning of image-bearing words and expressions is translated accurately in the majority of the analyzed contexts. Image grounding of the corresponding units in the source and target texts match completely or partially.

Image-bearing vocabulary of a literary text, as a rule, serve to express evaluation and to create expressiveness, therefore, match / mismatch of expressiveness and evaluation of the Russian and Turkish image-bearing unit of the text during translation is seen as an important feature of equivalency. As a rule, the translator tries to choose the image bearing vocabulary unit which matches the original unit in emotional, evaluation and expressive connotations. 
The degree of equivalency for image-bearing vocabulary units in different languages depends on match or mismatch of culture and symbolic associations. Similarity of a stable cultural background withdraws the search for alternative ways of its presentation in the other language. Thus, many organs and parts of human body are symbolically represented in a universal, common to all people way. For example, in both Russian and Turkish such expression as u nego pod nosom (burnudibindeki) means "near, close".

Cultural and symbolic connotations of precedent personal names, geographic names in particular, which are abundant in the novel (Istambul, Bosporus, Beyoğlu, etc.), have some peculiarities in translation. Thus, the central street Beyoğlu in Istambul, where all modern business centers, offices, banks, shopping malls are situated, is associated with western civilization for the native speakers of Turkish and symbolizes destroy of traditional culture and as result, basics of public morals. This toponym has negative culture-symbolic connotation associated with the desire to be modern and comply with the western trend, which in reality means to live immoral, criminal and evil life. To convey the same connotation in translation the translator uses image-bearing unit na chanzheskom rynke pokazuchi pod nazvaniem "Beyoglu" "sanctimonious market of showing of called Beyoğlu", which is absent in the source text.

Summing up the results of the analysis we can conclude that the author's images found in the source text are translated successfully and the equivalents chosen satisfy the goals and objectives of the literary text. Emotional effect of the source and the target texts is similar. Basic concepts constituting the author's model of the world and based on the key categories and images of Turkish culture are preserved. Despite some differences in details (on structural and semantic level of some vocabulary units, especially idioms) the target text is equivalent to the source text in terms of its figurativeness, metaphorical characteristics and expressiveness due to a large number of image-bearing vocabulary units and other language structures aimed to convey key images of the Turkish culture into Russian.

\section{References}

1. Yurina, E.A. (2005) Image-bearing system of language. Tomsk: Izdatel'stvo Tomskogo universiteta.

2. Alefirenko, N.F. (2008) Phraseology and cognitive study in terms of linguistic postmodern. Belgorod: Izdatel'stvo Belgorodskogo universiteta.

3. Ilyuchina, N.A. (1998) Image in lexical and semantic aspect. Samara: Izdatel'stvo Samarskogo universiteta.

4. Luk'yanova, N.A. (1986) Expressive vocabulary of colloquial use. Novosibirsk: Nauka.

5. Sklyarevskaya, G.N. (1993) Metaphor in language system. Saint-Petersburg: Nauka.

6. Teliya, V.N. (1996) Russian phraseology: Semantic, pragmatic and lingua cultural aspects. Moscow: Yazyki russkoy kul'tury. 
7. Blinova, O.I., Yurina, E.A. (2008) Image-bearing vocabulary of the Russian language. Language and Culture. 1. pp. 5-13.

8. Evans, V. (2009) How words mean: Lexical concepts, cognitive models and meaning construction. Oxford University Press.

9. Evans, V. (2013) Metaphor, Lexical Concepts, and Figurative Meaning Construction. Journal of Cognitive Semiotics. 1-2. pp. 73-107.

10. Glucksberg, S. (2001) Understanding Figurative Language - From Metaphors to Idioms. New York: Oxford University Press.

11. Raymond, W., Gibbs, Jr. (2001) Evaluating contemporary models of figurative language understanding. Metaphor and symbol. 16 (3 \& 4). pp. 317-333.

12. Lakoff, G., Jonson, M. (1980) Metaphors We live By. Chicago: University of Chicago Press.

13. Gibbs, R. (1992) Categorization and metaphor understanding. Psychological Review. 99 (3). pp. 572-575.

14. Barcelona, A. (2000) Metaphor and metonymy at the crossroads. Berlin: Mouton de Gruyter.

15. Baranov, A.N. (1991) Sketches on cognitive theory of metaphor. Russkaya politicheskaya metafora (materialy $k$ slovaryu). Moscow. pp. 185-189.

16. Chudinov, A.P. (2005) Metaphorical mosaic in modern political communication. Ekaterinburg: Ural. gos. ped. un-t.

17. Agayan, G.Z. (2006) Types of cross-language lexical equivalency. Razdel 5. Tekst, diskurs, problemy perevoda. Uchenye zapiski Tavricheskogo nazional'nogo universiteta im. V.I. Vernadskogo. Seriya "Filologiya". 19 (58). 2. pp. 155-159.

18. Breeva, L.V., Butenko, A.A. Lexical and stylistic transformations in translation [Online]. Available from: http://www.belpaese2000.narod.ru/Trad/trasform01.htm.

19. Komissarov, V.N. (1990) Translation theory (linguistic aspects). Moscow: Vysshaya shkola.

20. Kolganova, V.A. (2000) Lexical equivalency in literary translation from Dutch into Russian. Translation of metaphors. (Based on the novel "Het Geheim" by Anna Enquist). Diplomnaya rabota. Moscow.

21. Chervenkova, I.V. Speaking about equivalents in a comparative study of vocabulary [Online]. Available from: http://www.russian.slavica.org/article2284.html.

22. Shveyzer, A.D. (1988) Translation theory (status, problems, aspects). Moscow.

23. Imametdinova, G.F. (2009) Principles of semantic identification of lexical and phraseological units in literary translation from Tatar into Russian: based on the novel 'Lyubov', ob 'yataya plamenem" Ya.K. Zankieva. Philology Cand. Diss. Tyumen'.

24. Memetov, I.A. (2010). Peculiarities of Translation from Turkish. Uchenye zapiski Tavricheskogo nazional'nogo universiteta im. V.I. Vernadskogo. Seriya "Filologiya. Sozial'nye kommunikazii". 23 (62). 3. pp. 208-214.

25. Nemirovskaya, A.V. (2008) Metaphors in literary text: interactive approach to translation. Philology Cand. Diss. [Online]. Available from: http://www.dslib.net/jazykoznanie/nemirovskaja.html.

26. Schäffner, C. (2004) Metaphor and translation: some implications of a cognitive approach. Journal of Pragmatics. 36 (7). pp. 1253-1269.

27. Saygin, A.P. (2001) Processing figurative language in a multi-lingual task: Translation, transfer and metaphor. Proceedings of Corpus-Based \& Processing Approaches to Figurative Language. Workshop. Corpus Linguistics.

28. Pamuk, O. (2000) Kara Kitap. İstanbul: İletişim Yayınları.

29. Pamuk, O. (2000) Chernaya kniga per. s turez. V.B. Feonovoy. Saint-Petersburg: Amfora.

30. Karmazkaya, E.V. (2007) Comparative study of inner form and figurativeness in language system and perception of the native spekers: compound nominations in Russian and English case study. Philology Cand. Diss. Kemerovo. 